\title{
Autologous Mesothelin-specific CAR-T Cells
}

National Cancer Institute

\section{Source}

National Cancer Institute. Autologous Mesothelin-specific CAR-T Cells. NCI Thesaurus.

Code C148160.

Genetically modified, autologous T-lymphocytes transduced with a gene encoding a chimeric antigen receptor (CAR) specific for the human tumor-associated antigen (TAA) mesothelin, with potential immunomodulating and antineoplastic activities. After isolation, transduction, expansion in culture, and reintroduction into the patient, the autologous mesothelin-specific CAR-T cells specifically target and kill mesothelinexpressing tumor cells. Mesothelin, a cell surface glycoprotein involved in cell adhesion, is overexpressed in a variety of cancer cell types. 